\title{
Analysis and Possibilities of Increasing of Labor Potential in the Regions of the Volga Federal District (Russian Federation)
}

Glebova I.S.

Vorobyev A.A.

Garipova G.N.

\author{
Kazan Federal University, Institute of Management, Economics and Finance, Kazan, 420008, Russia
}

\section{Doi:10.5901/mjss.2015.v6n1s3p294}

\begin{abstract}
The article proposes a method of estimating of employment potential of a territory and results of the comparative analysis of employment potential of the Volga Federal District regions based on the method. There were also identified some problems of the regions and suggested ways of solving them.

Keywords: labor potential, index of labor potential of the region, absolute rate of labor force, working time fund, mechanical population growth, gross regional product.
\end{abstract}

\section{Introduction}

Labor potential is one of the subsystems of the human potential, its core. Effective reproduction of the human potential of the territory, as well as accelerate sustainable economic growth possibilities depend on forming, distribution and use of labor potential of the region. Necessity of improvements in labor force using is determined by objectively existing factors: the reduction in growth of the labor force because of general demographic trends; continuous increase in the number of employees allocated to non-productive sphere. The problem of measuring and forming the optimal set of qualitative characteristics of the labor force is relevant both in theoretical and practical aspect: due to the constant growth of the highly skilled workforce demand in regions it is necessary to estimate the employment potential of the region.

\section{State of the Issue}

At present the theory of labor potential is in its formative stages. There is yet no consensus on its conceptual framework, universally accepted theoretical and methodological approaches to understanding the nature and structure of the labor potential of the region, as well as mechanisms for its evaluation are not developed. There is a tendency to calculate labor potential of the region in several stages: a quantitative assessment of the labor potential of the region and calculation of influence of qualitative factors on the investigated parameters, using the index method. Quantitative assessment is an exact characteristics reflecting labor potential of the region. On its basis we can make a comparative analysis of the regions and construct a rating. At the same time, a qualitative assessment is a more complex process that characterizes the region, its own specific features and peculiarities more accurately.

\section{Review of the Literature}

Labour market is an essential element of the market economy, which is why many authors: Cho J., Lee T., Jung H.;[1] Galarza F.B., Yamada G.[2]; Bevelander P., Pendakur R.[3] refer to this concept. Deep investigation of the labor market is impossible without study of different aspects. For example Spiegel U., Gonen L.D., Weber M.[4]; and Viola I., Marinewwli N.[5] consider labor market through the prism of labor potential and define its basic concepts. Study of the theoretical aspects of the labor potential of the region is represented in the works of such authors as Russo G., Tedeschi F., Reggiani A., Nijkamp P.[6]; Crouch C.[7]; Muffels R., Wilthagen T.[8].

The main problem is that there is no consensus in defining of the boundaries of human resources, which are the basis of labor potential in the region, but almost all of the authors believe that correct mathematical calculations can 
become a key regulator of characterizing the degree of development of the region. Lack of awareness in the study of this category, according to George T.E., Yoon A.H.[9]; Kanbayashi H., Takenoshita H.[10]; Marx P.[11] inhibits the possibility of intensive development of the labor market.

\section{Research Methodology}

The first step is to analyze the structure of the labor force in the region. Absolute figure in the labor force is the sum of number of the able-bodied citizens and the number of working teenagers and the elderly. The labor force is fixed at a certain date, and so it becomes the torque indicator. However, such an indicator is not very useful for planning and economic calculations, so the interval is calculated as the arithmetic average rates (per month, quarter, year) form the torque indicators. Thus, it is possible to determine the total working population at the beginning of the period: $S_{\text {общ. }}=$ $S_{\text {тр.н. }}+S_{\text {пенс. }}+S_{\text {подр. }}[1]$, where - $S_{\text {общ. }}$ is the total number of the able-bodied citizens at the beginning of the period, $S_{\text {тр.н. }}$ - the number of the able-bodied citizens at the beginning of the period, $S_{\text {пенс. }}$ - the number of working pensioners, $S_{\text {подр. }}$ - the number of working teenagers up to 16 years. The number of employed people $\left(S_{\text {зан. }}\right)$ is also important.

An important indicator in the calculation of the labor potential of the region is the working time fund. It is calculated for a single individual. The total working time fund can be also calculated. A one- year interval is taken as a calendar period.

$\Phi_{\text {общ.р.в. }}=S_{\text {общ. }} * \Phi_{\text {инд.р.в. }}[2]$

To calculate the time fund both individual and general, we use 8 hours working day rate which is prescribed in the law. On average, if people have a five-day working week they work 247 days days per year is. On the basis of the data available, the personal working time fund $\left(\Phi_{\text {инд.р.в. }}\right)$ is calculated as the product of a working day rate by the number of working days per year. Substituting the obtained data into the formula [2] we obtain the general working time fund of the total able-bodied citizens $\left(\Phi_{\text {общ.р.в. }}\right)$.

The decisive parameter for the calculation of the full labour potential of the region is $U$ - the amount of output per

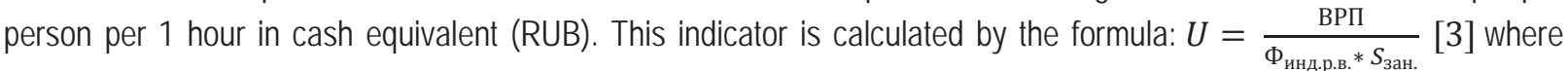
ВPП (GRP) - a gross regional product (indicator measuring the gross value added, calculated as the total gross production minus its intermediate consumption) $S_{\text {зан. }}$ - the number of the employed population in the region.

The data obtained can be used to find the total regional labor potential, which is expressed in the volume of output in monetary units. Using these data, the formula of the labor potential of the region is as follows: $\mathrm{T}_{\text {п.р. }}=U * \Phi_{\text {общ..в. }}$ [4]. To compare the figures of the labor potential of the region we can make their indexing $I_{\mathrm{T}_{\text {n.p. }}}$. The essence of this method is to assign index equal to 1 to the average figure, and determine other indices on the basis of the proportions in relation to the average figure.

To analyze the influence of qualitative factors that have the most significant impact on the labour potential of the region, the following parameters were chosen: fertility, mortality, migration, education, investment, health care. The hierarchy analysis was chosen for this method. We represent the data.

Table 1. Distribution of the coefficients of the parameters' impact.

\begin{tabular}{|c|c|c|c|c|c|c|c|c|c|}
\hline Significance & Mortality & Fertility & Migration & Education & Investment & Health care & $\begin{array}{l}\text { Geometric } \\
\text { mean }\end{array}$ & $\begin{array}{l}\text { Vector of local } \\
\text { priorities }\end{array}$ & $\begin{array}{c}\text { Coefficient of influence of the } \\
\text { parameter }\end{array}$ \\
\hline Mortality & 1 & 1 & $1 / 2$ & $1 / 4$ & $1 / 4$ & $1 / 3$ & 0,466545488 & 0,063692767 & 6,369276684 \\
\hline Fertility & 1 & 1 & $1 / 2$ & $1 / 4$ & $1 / 4$ & $1 / 3$ & 0,466545488 & 0,063692767 & 6,369276684 \\
\hline Migration & 2 & 2 & 1 & $1 / 4$ & $1 / 4$ & $1 / 3$ & 0,659794956 & 0,090075175 & 9,007517469 \\
\hline Education & 4 & 4 & 4 & 1 & 1 & 1 & 2 & 0,273039901 & 27,30399007 \\
\hline Investment & 4 & 4 & 4 & 1 & 1 & 1 & 2 & 0,273039901 & 27,30399007 \\
\hline Health care & 3 & 3 & 3 & 1 & 1 & 1 & 1,732050808 & 0,23645949 & 23,64594902 \\
\hline \multirow[t]{5}{*}{ Amount } & 15 & 15 & 13 & 3,75 & 3,75 & 3,99 & 7,32493674 & 1 & 100 \\
\hline & & & & & & & & & \\
\hline & & & & & & & eigenvalue= & 6,073032898 & \\
\hline & & & & & & & $\begin{array}{l}\text { consistency } \\
\text { index= }\end{array}$ & 0,01460658 & \\
\hline & & & & & & & $\begin{array}{c}\text { attitude } \\
\text { consistency= }\end{array}$ & 0,0117795 & matrix matched correctly \\
\hline
\end{tabular}


The table shows that the most weighty factors of the selected parameters affecting the labour potential are the following: education, health care, investments. An important factor is the calculation itself.

Birth and death rates have generally accepted calculation formula: $\mathrm{K}_{\mathrm{p} .}=\frac{N}{\bar{S}} * 1000$ where $\mathrm{N}$ is the number of births; $\bar{S}$ - average number of population per year. The death rate is calculated the same way: $\mathrm{K}_{\mathrm{cm} .}=\frac{M}{\bar{S}} * 1000$, where $\mathrm{M}$ - the number of deaths. These factors indicate how many births and deaths are accounted for 1,000 people. In order to reflect the process of natural population movement in the region it is necessary to find the difference between these two coefficients, so in the final formula, which produces the sum of the coefficients of the quality parameters affecting the labour potential of the region, the mortality rate is a negative indicator in absentia.

The evaluation of the mechanical population growth, which also affects the labour potential of the region is also important. The following formula for the calculation of the migration level is used: $\kappa_{\mathrm{m} .}=\frac{\Pi-B}{\bar{s}} * 1000$ where $\Pi$ is the number of arrivals in a given territory, $\mathrm{B}$ is the number of emigrants from the area. These indexes are fundamental and have the greatest impact on the coefficients of the labor potential of the region. Assessment of health care is based on comparing the level of expenditure on the budget line in the region. The same way is used to estimate the investments, so the regions comparison is based on the inflow of capital, that can be both external (foreign) and internal (investment entities of the Russian Federation). As for the evaluation of regions in terms of education, it is advisable to consider the ratio of number of people with higher and specialized education to the number of able-bodied citizens. This assessment allows to reflect the level of education in a given region more accurately.

Having both components of the labor potential coefficient of the region, we can calculate it with the formula: $K_{\mathrm{T}_{\text {n.p. }}}=I_{\mathrm{T}_{\text {n.p. }}} * \sum_{i=1}^{6}\left(K_{i} * x_{i}\right)$, where $K_{\mathrm{T}_{\text {n.p. }}}$ is the coefficient of the labor potential of the region, $I_{\mathrm{T}_{\text {n.p. }}}$ is the index of the labor potential of the region, $K_{i}$ is the coefficient of influence of i-th factor, $x_{i}$ is an indicator of $\mathrm{i}$-th factor. This formula shows the links between quantitative factors and qualitative factors of the labor potential of the region.

\section{Empirical Research: Main Results}

The coefficient of the labor potential of the region is an indicator of production capabilities of labor resources accumulated in the region in terms of influence of the factors that are close to the real economic situation of the region. Creating close to reality conditions for the coefficient calculating is really desire of the subject, that is conducting a research of this phenomenon. The peculiarity of this factor is that it can mathematically realize the impact of any factors affecting the labour potential of the region.

Table №2. Final results of the calculation of the labor potential of the regions in VFD for the end of the year 2012.

\begin{tabular}{|l|c|c|c|c|c|c|c|}
\hline Subjects of VFD & $\begin{array}{c}\text { Quantitative } \\
\text { index of labor } \\
\text { potential } \\
\text { (It.n.p.) }\end{array}$ & $\begin{array}{c}\text { The rate of } \\
\text { natural population } \\
\text { movement }\end{array}$ & $\begin{array}{c}\text { Migration } \\
\text { rate }\end{array}$ & $\begin{array}{c}\text { Ratio of } \\
\text { expenditure } \\
\text { on education } \\
\text { per capita }\end{array}$ & $\begin{array}{c}\text { Ratio of health } \\
\text { expenditure per } \\
\text { capita }\end{array}$ & $\begin{array}{c}\text { Ratio of } \\
\text { investment per } \\
\text { capita }\end{array}$ & $\begin{array}{c}\text { The coefficient of } \\
\text { the labor potential } \\
\text { of the region }\end{array}$ \\
\hline $\begin{array}{l}\text { Republic of } \\
\text { Bashkortostan }\end{array}$ & 2,136 & 1,4 & $-2,31$ & 1,04 & 1,00 & 0,86 & 136,41 \\
\hline Republic of Mari El & 0,215 & 0,6 & $-3,33$ & 0,89 & 0,71 & 0,67 & 7,15 \\
\hline Republic of Mordovia & 0,249 & $-4,5$ & $-4,15$ & 0,85 & 1,12 & 0,90 & 2,12 \\
\hline Republic of Tatarstan & 2,471 & 2,3 & 3,15 & 1,14 & 1,01 & 1,84 & 366,32 \\
\hline Republic of Udmurtia & 0,639 & 2,4 & $-2,53$ & 1,15 & 1,16 & 0,57 & 42,83 \\
\hline Republic of Chuvashia & 0,386 & 0,7 & $-2,20$ & 0,89 & 0.86 & 0,79 & 19,63 \\
\hline Perm region & 1,515 & 0,6 & $-0,31$ & 1,15 & 1,13 & 0,91 & 127,14 \\
\hline Kirov region & 0,394 & $-2,8$ & $-4,20$ & 1,05 & 0,83 & 0,57 & 3,32 \\
\hline Nizhny Novgorod region & 1,425 & $-4,2$ & 2,12 & 0,93 & 1,15 & 1,18 & 110,17 \\
\hline Orenburg region & 1,171 & 0,8 & $-3,48$ & 1,01 & 1,05 & 1,12 & 66,75 \\
\hline Penza region & 0,427 & $-4,1$ & $-0,27$ & 0,76 & 0,91 & 0,79 & 15,09 \\
\hline Samara region & 1,627 & $-1,8$ & 2,57 & 0,97 & 1,02 & 0,96 & 143,95 \\
\hline Saratov region & 0,860 & $-2,9$ & $-0,36$ & 0,90 & 0,73 & 0,68 & 33,20 \\
\hline Ulyanovsk region & 0,438 & $-2,8$ & $-2,50$ & 0,82 & 0,98 & 0,86 & 12,59 \\
\hline VFD & 1 & $-0,7$ & $-0,42$ & 1 & 1 & 1 & 70,05 \\
\hline
\end{tabular}

Investigating the coefficients of the regional labor potential in the table №2, we can draw several conclusions. Obviously, the Republic of Tatarstan has the best parameter of the labor potential in the Volga Federal District, which is $\left(K_{T_{\text {n.p. }}}=\right.$ $366,32)$. It is obvious due to the indicators that were observed in the demographic, social and economic spheres. The 
main role belongs to the positive dynamics of natural and mechanical population growth, as well as substantial amounts of investment in fixed assets in the region. The second place is taken by Samara region $\left(K_{T_{\text {T.p. }}}=143,95\right)$, the third place has the Republic of Bashkortostan with the index $\left(K_{\mathrm{T}_{\text {n.p. }}}=136,41\right)$.the Nizhny Novgorod region has quite law results $\left(K_{T_{\text {n.p. }}}=110,17\right)$, though Nizhny Novgorod, the capital city of the region is the center of the PFD. The region took only the 5th place after the Perm region $\left(K_{\mathrm{T}_{\text {n.p. }}}=127,14\right)$. The lowest rates of labor potential are registered in the Republic of Mordovia $\left(K_{\mathrm{T}_{\text {n.p. }}}=2,12\right)$ and the Kirov region $\left(K_{\mathrm{T}_{\text {n.p. }}}=3,32\right)$. The average index for the Volga Federal District is $\left(K_{\mathrm{T}_{\text {n.p. }}}=\right.$ $70,05)$.

The figures above show a high differentiation between the PFD subjects. We can see difference not only in the economic development of the regions, but also in the results of the socio-demographic policies in a particular region. After analyzing these data, we can note current and competent policy conducting in the Perm region. The Government of the subject distributes and spends funds effectively in all spheres of the region It can also be seen in comparison with the Udmurt Republic which does not have competent policy of attracting investment in fixed assets, and does not minimize the mechanical loss of population. The coefficient of the labor potential of the region would be much higher if funds from the budget were distributed evenly. For example, instead of excessive spending money on education and health care, there could be financed some measures to reduce mechanical loss of population. Actually the region has become a workforce donor preparing a healthy and educated population to other regions.

\section{Conclusion}

Thus, the existence of a high level of differentiation between the regions of the Volga Federal District was revealed. Tatarstan has become the leader in terms of the labor potential, whereas the Kirov Region and the Republic of Mordovia took the last places. A factor analysis shows the main problems of the regions such as natural and mechanical population loss, low levels of literacy and health, as well as low investment attractiveness of the regions. In addition, the price of labor remains extremely low, leading to stagnation of labor potential, reducing motivation to effective work and creativity, self-improvement and focus on qualitative change in the parameters of the environment. These conclusions were based on the ratio of labor potential of Mordovia and the Kirov region.

The regions of the Volga Federal district are experiencing the effects of the demographic crisis of the 90-ies. In half of the regions there is a natural decline in the population. The solution to this demographic problem is possible by creating conditions for socio-economic assistance to promote fertility: increasing the size of the payments of the parent capital, as well as creating additional benefits for young families and so on

Creating a positive growth trend in terms of the labour potential of the region is possible only with a uniform regulation of demographic, migration and socio-economic policies as well as taking into account specific problems of each region.

Thus, in the Republic of Bashkortostan, Perm region and Orenburg region we can observe the basic problem of mechanical loss of population. This problem can be solved by creating conditions to attract the highly skilled workforce. Mechanical population decline is directly related to errors in the current social policy in the regions. If the level of education and health care is higher than in average, the housing policy and wage levels still have much to be desired. It is necessary to implement programs to improve housing affordability and increase in average wages.

We can observe a difficult situation in the social sector in Kirov, Penza, Saratov, Ulyanovsk region and the Republic of Mordovia. Apart from the problems in the housing sector and the low level of wages they have even a lower level of health care and education. These problems can be solved only with a full modernization of material and technical resources and professional development of the staff working in the health sector. Changing the priorities in the education system, for example, distance learning will improve the overall level of education of the population.

Almost all regions of the Volga Federal District have the lack of investment in fixed assets. Solution of this problem is possible using the experience of the Republic of Tatarstan in creating special economic zones and reducing administrative barriers for business. Proper regional policy will contribute to solving social and demographic problems, which will have a positive impact on the labour potential of the region.

\section{References}

Cho J., Lee T., Jung H.. Glass ceiling in a stratified labor market: Evidence from Korea // Journal of the Japanese and International Economies (32), 2014, pages 56-70.

Galarza F.B., Yamada G.. Labor market discrimination in Lima, Peru: Evidence from a field experiment // World Development (58), 2014, 
pages 83-94.

Bevelander P., Pendakur R.. The labour market integration of refugee and family reunion immigrants: A comparison of outcomes in Canada and Sweden // Journal of Ethnic and Migration Studies (40), 2014, pages 689-709.

Spiegel U., Gonen L.D., Weber, M.. Duration and optimal number of shifts in the labour market // Applied Economics Letters (21), 2014, pages 429-432.

Viola I., Marinewwlli, N.. Green orientation in the food industry and labour market // Quality - Access to Success (15), 2014, pages 154158.

Razumovskaya, E.M. , Kutsevol, N., Popov, M., Mishakin, T., Leto, L., Tsalikova, V. The effectiveness of management practice in the market of socially important services, Asian Social Science, Volume 10, 28 September 2014, Pages 118-122

Russo G., Tedeschi F., Reggiani A., Nijkamp P.. Commuter Effects on Local Labour Markets: A German Modelling Study // Urban Studies (51) 2014, pages 493-508.

Bagautdinova, N.G., Fatkhiev, A.M., Novenkova, A.Z., Safiullina, A.M. (2014). The stages of the innovation process. Recent Trends in Social and Behaviour Sciences - Proceedings of the 2nd International Congress on Interdisciplinary Behavior and Social Sciences 2013, ICIBSoS 2013, Pages 315-318.

Crouch C.. Introduction: Labour markets and social policy after the crisis // Transfer (20), 2014, pages 7-22.

Muffels R., Wilthagen T.. Flexibility and security: National social models in transitional labour markets // Transfer (20), 2014, pages 99114.

George T.E., Yoon A.H.. The labor market for new law professors // Journal of Empirical Legal Studies (11), 2014, pages 1-38.

Razumovskaya, E.M., Mishakin, T.S., Popov, M.L., Kucevol, N.G. Medical services during the XXVII world summer universiade 2013 in Kazan. Mediterranean Journal of Social Sciences, Volume 5, Issue 18 SPEC. ISSUE, 2014, Pages 17-20.

Kanbayashi H., Takenoshita H.. Labor market institutions and job mobility in asian societies: A comparative study of Japan and Taiwan // International Journal of Japanese Sociology (23), 2014, pages 92-109.

Marx P.. Labour market risks and political preferences: The case of temporary employment // European Journal of Political Research (53), 2014, pages 136-159. 